\title{
Infestation of a Complementary Food by Tribolium Castaneum Herbst Macleay 1825 (Coleoptera: Tenebrionidae)
}

\author{
Fatimé Ardjoune Adji* \& Ngamo Tinkeu L.S*. \\ * Department of Biological Sciences, Faculty of Sciences, University of Ngaoundere, \\ PO BOX 454 Ngaoundere, Cameroon
}

\begin{abstract}
During storage of complementary foods in the form of flour, secondary pests attacked including $T$. castaneum. To evaluate these depreciation two formulations were elaborated using infested insects in $1200 \mathrm{ml}$ jars with 11 repetitions for each. After 90 days of infestation, emergences were noted. The average sizes of the different stages showed that the formulation with bambara groundnut was that which noted the most emergences. The average of stage $\mathrm{I}$ is $68.4 \pm 26.3$ in the formulation with bambara groundnut and $29.2 \pm 14.1$ in that without. The same is true for stage $\mathrm{V}$ and in the adults where the emergences respectively were $111.9 \pm 45.3$ and $397.2 \pm 130.6$ in formulation with bambara groundnut and $46.8 \pm 15.6$ and $164.7 \pm 22.5$ in the formulation without.
\end{abstract}

Key words: formulation, $T$. castaneum, storage, depreciation, infestation

\section{Introduction}

Flour, a product from grain milling, is one of the main calorie inputs of human nutrition. It is associated with flour from legumes that are a source of protein (Kouebou et al., 2013) for the constitution of high-nutrient infant supplement foods from six months of age (Cheftel and Cheftel, 1985). However, during its conservation it is damaged by several factors which at the origin of depreciation of its leptic and physical quality. The biotic factors that depreciate are mainly represented by certain Coleoptera species, in this case T. castaneum (Tapondjou et al., 2002), classified as a secondary pest (Ngamo et al., 2007). Insects consume particularly the protein matter of the flour and allow the products of metabolism. They also increase in a relative manner the starch rate, characterized by its great capacity to absorb water (Mbadja, 1989). The purpose of this work is to evaluate the depreciation of this insect on the complement food elaborated.

\section{Material and methods}

\section{Permanent breeding of Tribolium castaneum}

The insects come from the infested wheat flour bought from the market of Yagoua, Far North Region of Cameroon. In five glass jars of $1200 \mathrm{ml}$, with perforated lid, 200mg of rice flour are introduced, and then 20 adult insects are added. Ten days (laying time) after sieving, adults are removed from the jar to let the new generation evolve with ambient temperature.

\section{Composition of the formulation}

Two formulations were made from the bambara groundnut and rice flour as shown in Table 1. The first formulation consists of $15 \%$ bambara groundnut flour $+75 \%$ rice flour $+5 \%$ sugar and $5 \%$ peanut oil (Barennes, 2005). The second formulation without bambara groundnut which serves as the control consists of $90 \%$ rice flour $+5 \%$ sugar $+5 \%$ peanut oil. The food was weighed using a NOVA brand electronic scale $1 \mathrm{~g}$ of precision. 
Table 1. Composition of formulations with different proportions (\%)

\begin{tabular}{lcc}
\hline & $\begin{array}{c}\text { Formulation with bambara } \\
\text { groundnut }\end{array}$ & $\begin{array}{c}\text { Formulation without bambara } \\
\text { groundnut }\end{array}$ \\
\hline Rice flour & 75 & 90 \\
bambara flour & 15 & 0 \\
Sugar & 5 & 5 \\
Oil & 5 & 5 \\
\hline Final weight formulation & 100 & 100 \\
\hline
\end{tabular}

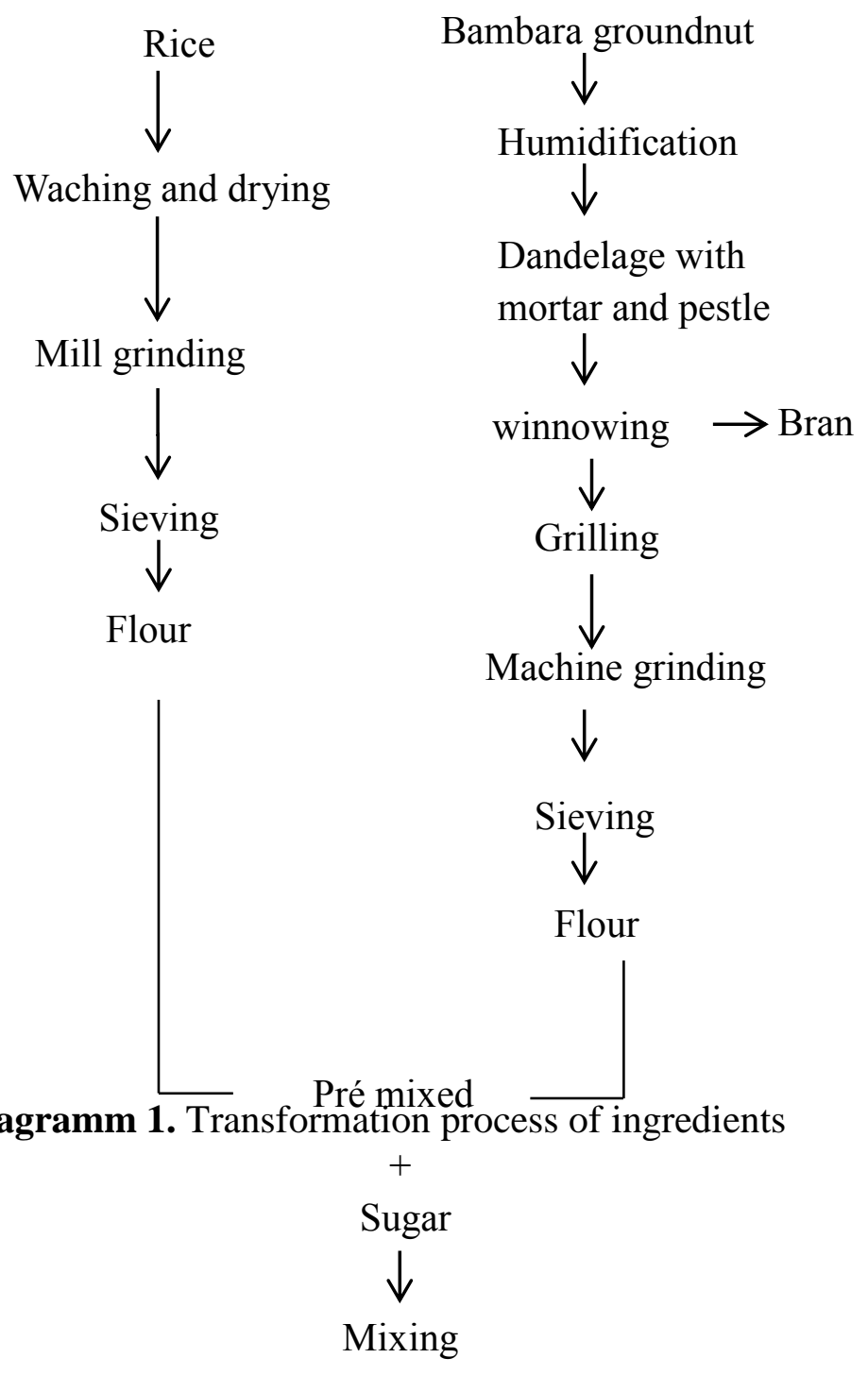

\section{Determination of infestation level}

In $1200 \mathrm{ml}$ glass jars, $210 \mathrm{~g}$ of the formulation were introduced with 11 replicates. Adults T. castaneum of the same stage development were added to each jar after differentiating the sexes. The first sieving took place after 10 days to remove adult insects. At 90 days of infestation the second sieving was done as well as the counting and also to evaluate the level of infestation and determine the different stages of development. The different larval stages were determined using a graph paper.

\section{Statistical analysis}

The statistical analysis was carried out by the Excel software for the calculation of averages and standard deviations of the different stages of development. 


\section{Results and discussion}

90 days after infestation, all larval stages, nymphal, and adults are present in both formulations. The averages of the sizes of stage I to stage $\mathrm{V}$ of the formulation with bambara groundnut are greater than those of the formulation without. The same is true of the nymphal and adult stage. There is a significant difference $(\mathrm{P} \leq 0.05)$ between the averages for the Kolmogorov-Smirnov tests. Stages III, V and adults have average numbers greater than 100 for the formulation with bambara groundnut, while for formulation without only the number of adults is greater than 100 (Table 2). These would be due to the composition of nutrient-rich formulation with bambara groundnut. According to Delobel and Tran (1993), the number of eggs laid can vary according to the food in which they develop. Insect tolerances are stricter in finished commodities such as flour or cornmeal. The defect action level set by the Food and Drug Administration for insect and insect fragments is one or more whole insects per 50 grams or an average of 25 or more insect fragments per 25 grams (Food and Drug Administration 2009).

Table 2. Average workforce of both formulations

\begin{tabular}{lccccccc}
$\begin{array}{l}\text { Stages of } \\
\text { development }\end{array}$ & I & II & III & IV & V & nymphal & Adult \\
\hline $\mathrm{AB}$ & 68,4 & 81,9 & 100,7 & 68,8 & 111,9 & 55,9 & 397,2
\end{tabular}

Standard

\begin{tabular}{llllllll} 
deviation & 26,3 & 27,9 & 27,6 & 25,6 & 45,3 & 42,8 & 130,6 \\
\hline AEWB & 29,2 & 38,5 & 47,0 & 35,5 & 46,8 & 13,9 & 164,7
\end{tabular}

Standard

$\begin{array}{llllllll}\text { deviation } & 14,1 & 12,5 & 19,1 & 7,7 & 15,6 & 15,8 & 22,5\end{array}$

$\mathrm{AB}$ : average of effectives of formulation with bambara groundnut ; AWB : average of effectives of a formulation without bambara groundnut

From the averages of the data obtained a histogram has been plotted as shown in Figure 1.

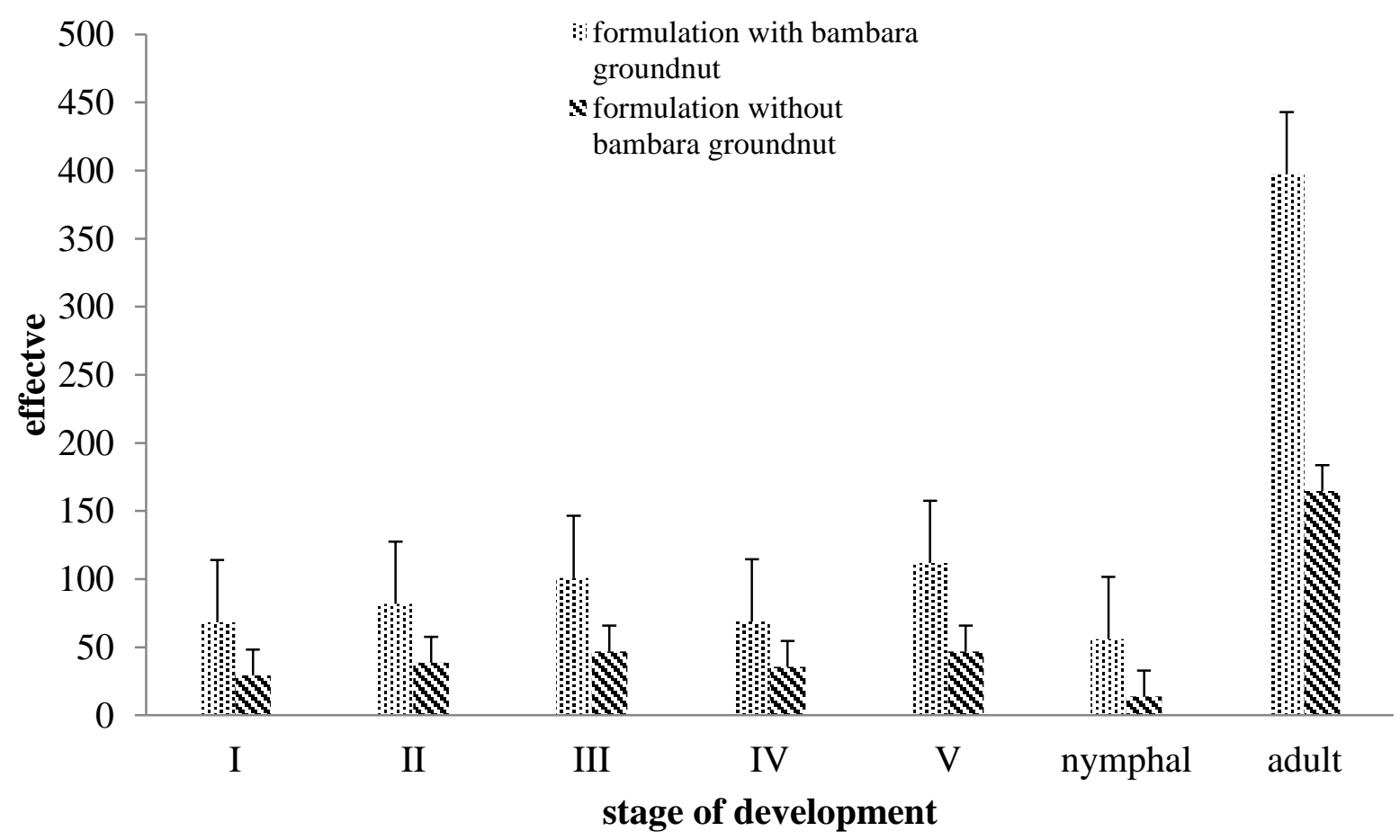

Figure 1. Infestation level by stage of development 


\section{Conclusion}

The results show that there is favorable development of $T$. castaneum in the formulation with bambara groundnut according to the infestation level of the insect. This formulation is attacked more with the important emergences in all the larval stages and adult than the formulation without bambara groundnut. Hence there is need for conservation tool in order to preserve food and nutritional quality which provides a good role for complementary food for infants.

\section{References}

1. Cheftel J. C. \& Cheftel M., 1984. Introduction à la biochimie des transformations des aliments. Tecniques et documentation, Lavoisier Paris $1: 105-141$.

2. Food and Drug Administration, 2009. Defect Levels Handbook. The Food Defect Action Levels. Levels of natural or unavoidable defects in foods that present no health hazards for humans.http://www.fda.gov/food/guidancecomplianceregulatoryinformation/guidancedocuments/san itation/ ucm056174.htm\#CHPTA. Accessed April 2011.

3. Kumar R., 1991. La lutte contre les insectes ravageurs : situation de l'agriculture africaine. CTA/ Karthala. Eds. Wageningen, Paris, 310p.

4. Kouebou C. P., Achu M.; Nzali S., Machawe Chelea., Bonglaisin J., Kamda A., Djiele P.,

5. Mbadja J. C., 1989. Recherche de l'influence des mites sur la farine entière de boulangerie. Mémoire de fin d'étude d'ingénieur de travaux, ENSIAAC. Centre Universitaire de Ngaoundéré. $58 \mathrm{p}$.

6. Ngamo T. L. S., Goudoum A., Djakissam W., Madou C., 2006. Les bruches du voandzou Vigna subterranea (L.) et les outils de protection post récolte dans le Nord du Cameroun. Entomologie Faunistique - Faunistic Entomology 2016, 69, 83-89.

7. Taponjou L. A.; Adler C.; Bouda H. \& Fontem D. A.; 2002. Efficacy of powder and essential oil from Chenopodium ambrosioides leaves as post-harvest grain protectants against six-stored product beetles. Jounal of Stored Product Research, 38: 395-402.

8. Yadang G., Ponka R., Ngoh Newilah G., Nkouam G., Teugwa C. \& Kana Sop M. M., 2013. A review of composition studies of Cameroon traditional dishes: Macronutrients and minerals. Food Chemistry, 1-7. 